\title{
Land-use and rural inequality profiles in the province of Barcelona in mid-nineteenth century
}

\author{
Enric Tello \& Marc Badia-Miró
}

KEYWORDS: agricultural income distribution, land use patterns, inequality possible frontier, extraction ratios.

\author{
JEL CODES: N53, D31, H24, Q15.
}

he long-term impact on income inequality of agricultural commercial spe-
cialization is still an open-ended discussion. Diverse economic models and ap-
proaches offer competing views, while historians increasingly stress the contingent nature of the paths followed in the various contexts. Applying common inequality indices like the Theil index along with new ones such as the inequality possible frontier (IPF) and Inequality Extraction Ratios (IER), this study examines how winegrowing specialization in Catalonia correlated with agricultural income distribution in the municipalities of the province of Barcelona during the mid-nineteenth century. This analysis examines a large dataset assembled from over 86,000 cadastral taxpayers in 292 municipalities and recorded in the Distribution of Personal Wealth in Real Estate Ownership of the province of Barcelona in 1852, combined with other population and land use data listed in the Estadística territorial de la provincia de Barcelona (Land Use Statistics of the Province of Barcelona), compiled in 1858. The results confirm that inequality in agricultural income distribution was lower in predominantly winegrowing municipalities than in timber and cereal-growing ones, despite the fact that commercial specialization and higher population densities could have extended the inequality possible frontier of those winegrowing areas in the mid-nineteenth century. 


\title{
Perfiles de la desigualdad rural y los usos del suelo en la provincia de Barcelona a mediados del siglo XIX
}

\author{
PALABRAS CLAVE: distribución de los ingresos agrarios, propiedad \\ de la tierra, patrones de uso del suelo, presión fiscal.
}

\section{CÓDIGOS JEL: N53, D31, H24, Q15.}

limpacto sobre la desigualdad de ingresos de los procesos de especialización co-
mercial agrícola es un tema de investigación abierto. Diversos enfoques y mo-
delos económicos difieren, mientras los historiadores subrayan el carácter contingente de las trayectorias seguidas en distintos contextos. Vamos a estudiar cómo la especialización vitivinícola catalana se correlaciona con la distribución del ingreso agrario en los municipios de la provincia de Barcelona a mediados del siglo XIX, mediante indicadores de desigualdad habituales como el índice de Theil, junto con otros nuevos como la frontera de máxima desigualdad posible (IPF) y las tasas de extracción de la desigualdad (IER). Aplicamos este análisis a una base de datos con más de 86.000 contribuyentes de 292 municipios registrados en la Distribución Personal de la Riqueza Territorial en la provincia de Barcelona en 1852, combinados con datos de población y uso del suelo de la Estadística territorial de la provincia de Barcelona, de 1858. Los resultados confirman que la desigualdad en la distribución del ingreso agrario era menor en los municipios vitícolas que en los principalmente forestales o cerealicolas, aunque la especialización y mayor densidad de población de las zonas vitícolas podrian haber ampliado la frontera de máxima desigualdad a mediados del siglo XIX.

Received : 2016-04-04 - Revised: 2017-11-18 - Accepted: 2017-11-28

Enric Tello [http://orcid.org/0000-0002-4970-1524] is Professor of the Department of Economic History, Institutions, Policy and World Economy at the University of Barcelona (Spain), BEAT (Barcelona Economic Analysis Team) and Centre Estudis "Antoni de Capmany". Address: Faculty of Economics and Business, Diagonal Avenue 690, 08034 Barcelona (Spain).E-mail: tello@ub.edu

Marc Badia-Miró [http://orcid.org/0000-0001-5326-1819] is Lecturer of the Department of Economic History, Institutions, Policy and World Economy at the University of Barcelona (Spain), BEAT (Barcelona Economic Analysis Team) and Centre Estudis "Antoni de Capmany". Address: Faculty of Economics and Business, Diagonal Avenue 690, 08034 Barcelona (Spain).E-mail:mbadia@ub.edu 


\section{INTRODUCTION}

What impact does agricultural commercial specialization entail on income inequality? There is no clear consensus in the literature to answer this question. To begin with, if market integration leads to a rise in total income and wealth in a region, this would also involve an upward shift of the maximum inequality possibility frontier, which in turn might lead to an increase in the actual extraction ratio taken by a small elite (Milanovic, 2011; Milanovic, Lindert \& Williamson, 2011). Whether the latter happens or not depends on other factors at stake and, when considering them, diverse economic approaches and models differ (Williamson, 1991, 1999, 2009; O'Rourke \& Williamson, 1999; Bourguignon \& Morrisson, 2002; Lindert \& Williamson, 2003; Piketty, Postel-Vinay \& Rosenthal, 2006; Acemoglu \& Robinson, 2006; Atkinson \& Piketty, 2007; Hornborg, McNeill \& Martínez Alier, 2007; Prados de la Escosura, 2008; Roine \& Waldenström, 2009; Piketty, 2014). For example, the Stolper-Samuelson theorem states that under a Heckscher-Ohlin model of trade, a rise in the relative price of a good will lead to an increase in the return to the factor that is used most intensively in the production of the good traded, and to a fall in the return to the other factors less intensively used.Yet, this does not apply when a commercial specialisation sets in motion the advance of an agricultural frontier that extends the cropland area of the commodity being grown and sold abroad -at least as long as the frontier remains open (Greasley, Inwood \& Singleton, 2007; Harley, 2007; Santiago-Caballero, 2011; Badia-Miró \& Tello, 2014). These examples stress the importance of several contingent historical factors that frame how the disputed entitlement of natural resources affects who benefits from their use (Badia-Miró, Pinilla \& Willebald, 2015).

The discussion above makes it very relevant to study how the agricultural specialization in brandies and wines that took place in Catalonia since the mid- $17^{\text {th }}$ century to the Phylloxera plague in the late $19^{\text {th }}$ century affected income inequality (Vilar, 1962; Giralt, 1965; Valls-Junyent, 2004; Badia-Miró \& Tello, 2014; Colomé et al., 2016). Many historical monographs have pointed out that the spread of vineyards in this north-eastern corner of the Iberian Peninsula led to a less unequal rural society (Garrabou, Tello \& Cussó, 2008; Garrabou et al., 2009; Badia-Miró \& Tello, 2014; Tello \& Badia-Miró, 2015). Nevertheless, most available evidence comes from cadastral sources which, in most cases, did not make a clear distinction between landownership rents and the incomes obtained by winegrowers who were holders of tenancy contracts. This is an important shortcoming which may have led to overestimate the actual reduction in income inequality (Valls-Junyent, 1997; Colomé, 2013; López Estudillo, 2016). Using a large dataset assembled through an unexploited source on agricultural incomes recorded in the province of Barcelona in mid- $19^{\text {th }}$ century, we therefore test the hypothesis put forward by previ- 
ous local case studies that the Catalan vineyard specialization led to a reduction of inequality in agrarian income distribution (Tello, Garrabou \& Cussó, 2006; Colomé, Planas \& Valls-Junyent, 2015).

According to the available case studies, there would have been two specific mechanisms at stake, one direct and another indirect. The direct mechanism was the leasing of small plots of land from well-off landowners to landless winegrowers through a traditional sharecropping contract called in Catalan rabassa morta (Badia-Miró et al., 2010; Badia-Miró \&Tello, 2014; Carmona \& Simpson, 1999; Garrido, 2017a, 2017b, 2017c). The tenancy established by this peculiar long-lease emphyteutic contract lasted until the death of the vines planted by the tenant. Given that before the Phylloxera plague winegrowers used to bury strains of their old vines in order to keep them alive, the rabassa tenants tried to maintain their access to land almost permanently. The duration of the contract, together with the rent share taken by the landowner from the vintage harvested by the winegrower, gave rise to a long-lasting class conflict from the end of the $18^{\text {th }}$ century until the Spanish Civil War in 1936-39 (Balcells, 1980; Valls-Junyent, 1997; Tello, 1997; Carmona \& Simpson, 1999; Simpson, 2011; Colomé, 2013; Colomé et al., 2016). Despite the conflicting social relationship between landowners and tenants, the fact that the rabassa tenancy system became so widespread might also be acknowledged as an achievement by the poorest sections of the Catalan rural society thanks to their bargaining power and collective action (Garrabou, Planas \& Saguer, 2001a; Garrabou \& Tello, 2002).

The second indirect mechanism through which vineyard specialization could have led to a reduction in landownership and agrarian income inequalities was the ability of many rabassa tenants to subsist from their vines, endure the pressure of the rent taken by the owner, and prosper enough to buy a small house, an adjoining garden and even a plot of their own. It is important to note that many of these landless tenants were immigrants initially coming from Southern France and the mountain villages of the Pyrenees (Nadal \& Giralt, 1960). Some others, however, came from the non-inheriting progeny of the same class of well-off peasants who offered them rabassa tenancies. Furthermore, as non-heirs, they received a legitimate compensation from the first-born brother heir, which was paid either in cash or with a small plot of land. This second mechanism restrained landownership inequality, while the spread of rabassa tenancies only reduced the inequality of income distribution. Taken together, both mechanisms entailed an improvement of access to land and agrarian incomes that the rabassa tenants managed to achieve in winegrowing municipalities. These options were not so available to the poorest sectors of Catalan rural society in mainly cereal-growing, forest and livestock-grazing areas. In this sense, we may say that Catalan winegrowing tenants managed to harness the ongoing process of population growth, commercial specialization and agricultural intensification to carry out 
a genuine process of socioeconomic empowerment (Badia-Miró \& Tello, 2014; Tello \& Badia-Miró, 2015).

The most apparent feature of agrarian settlement in most of the province was a network of scattered poly-cultural farms called masies in Catalan, structured into compact land units around an isolated rural dwelling. Thanks to the late medieval peasant struggles held in Catalonia before and after the Black Death, the well-off landowners who lived in these masies gradually gained control of the rights of access to cropped and uncultivated land over a complex and conflictive transition from feudalism to agrarian capitalism (Garrabou, Tello \& Cussó, 2008; Congost, 2015). From the $17^{\text {th }}$ century onwards, population growth was fostered by increasing French immigrants and higher fertility. The owners of the scattered farms saw these immigrants, and the disinherited descendants of the old local families, as a new and frightening landless class that tried to settle down in the villages or towns between their networks of masies.

However, landowners soon discovered new opportunities to take advantage of the lack of land and labour availability of this landless class, and of the high relative prices of brandy or wine at that time, by expanding the inner winegrowing frontier and leasing to them some marginal lands to plant vineyards (Colomé et al., 2013). Many landless families became winegrowers through the emphyteutic rabassa contract, and a new social geography appeared when a patchwork of small vineyard plots arose among the interstices of the old polycultural masies (Marull et al., 2010; Olarieta, RodríguezValle \& Tello, 2008; Tello, Garrabou \& Cussó, 2006). This poorest share of population used to live in the streets of small towns or villages. While the shape of the diverse compact fields of every masia tended to be higher and be located around a scattered farmhouse, the small plots of vineyards planted by the rabassers used to be orientated towards the old villages, or even to the new ones created by these winegrowers, following the existing ways and roads (Garrabou, Tello \& Cussó, 2008; Colomé, Cucurella-Jorba \& Valls-Junyent, 2010; Colomé \& Valls-Junyent, 2012).

Some local case studies on these vine-growing municipalities have shown a decrease in the Gini coefficients of landownership distribution from the beginning of the $18^{\text {th }}$ century up to the Phylloxera plague (Garrabou, Tello \& Cussó, 2008; Garrabou et al., 2009). Later, when every old vine had been ravaged during the 1880 s, all the rabassa contracts came to an end, and many tenants were evicted or gave up winegrowing, landownership distribution became more unequal again. In other areas, however, vineyards were replanted; many rabassa tenancies persisted, and with them the conflicts about the rent shares and land entitlements lasted another half a century up to the Spanish CivilWar and Franco's dictatorship (Badia-Miró et al., 2010; Colomé, 2013; Colomé et al., 2016). Anyway, could this pathway be generalized assuming that the reduction in inequality of the 
rural Catalan society up to mid- $19^{\text {th }}$ century was a general trend triggered by the spread of vineyard specialization?

We can find in the existing literature on the Catalan vineyard specialization some trends which might have counterbalanced the factors listed above that favoured a less unequal rural society (Colomé et al., 2013). First, commercial specialization could attract more immigrants to the municipalities where vineyards were spreading, and also foster population growth in them by increasing birth rates, thus growing the number of people who owned only very small plots or had no land of their own (Valls-Junyent, 1997; Colomé et al., 2010). Secondly, the spread of vineyards also raised the total income and wealth of the whole rural community. As Milanovic, Lindert and Williamson (2011) have pointed out, a wealthier economy could also mean the possibility to increase the extraction ratio taken by a small elite. Thirdly, many historical examples do show that an increase in market integration and globalization have led to greater inequality and not the opposite (Hornborg, McNeill \& Martínez Alier, 2007). Even adopting a standard HeckscherOhlin approach, this could be the expected outcome when land was still the most abundant factor endowment in a region joining a global market (Acemoglu, Robinson \& Johnson, 2002; Acemoglu \& Robinson, 2006).

\section{INEQUALITY OF WHAT, AND AMONG WHOM?}

Having these historical and theoretical considerations in mind, we cannot take for granted that the reduction of inequality in landownership or agrarian incomes was a general trend in the province of Barcelona, without carrying out a cross-section analysis encompassing a great deal of municipalities. To do this, we have employed as a main source the Distribution of Personal Wealth in Real Estate Ownership published in the Official Gazette of the Barcelona province in 1852. This very exceptional document lists for each of the municipalities the names of all owners of land, houses and livestock who were subject to payment of the cadastral tax, adding up the monetary evaluation of their taxable incomes and annual tax burden paid. Drawn from this source, we have been able to include in our database more than 86,000 taxpayers in 292 municipalities for which we also had data on the land use patterns, out of the 311 existing at present in the province. These real estate owners represented $12 \%$ of the total population, $24 \%$ of all males, and $41 \%$ of all male inhabitants older than 21 recorded in the provincial census of 1857 . The second main source used in our database is a Land-Use Statistics of the Province of Barcelona compiled in 1858 by a Spanish topographer, Pedro Moreno Ramírez (2011[1858]), which lists the total agrarian area and the extent occupied for each agricultural, forest or pastureland use in each municipality. This information has been com- 
bined with the 1857 population census, so as to construct a dataset to correlate the land use profiles and agrarian income inequality in 292 municipalities of the province of Barcelona in mid- $19^{\text {th }}$ century.

The Distribution of Personal Wealth in Real Estate Ownership of 1852 is a very exceptional source. According to the Royal Order issued by the then Managing Director of Taxes, Statistics and State Heritage, all Spanish provinces had to publish in their Official Gazettes the whole list of taxpayers with their names, the taxes they paid, and tax burden applied (Bravo, 1852). Such unusual transparency can only be understood in the context of the initial efforts to legitimate a modern land tax system to be developed by the Spanish liberal governments after the new Tax Act passed in 1845. Unfortunately, these efforts failed to achieve their ultimate goals for over a century. During the $19^{\text {th }}$ century and the first third of the $20^{\text {th }}$ century the Spanish liberal governments never ended the cadastral maps and enquiries needed to assess an income value for each land unit devoted to a specific crop, so as to apply a uniform tax burden to every taxpayer (Muro, Nadal \& Urteaga, 1996).

Due to the Spanish long-lasting failure in completing a true cadastral survey, a temporary tax system called amillaramientos was established. Instead of following a bottom up process to comply with the most basic principle of tax equity, the system of amillaramientos ran top to bottom. Each year the provincial quotas were politically distributed in the Spanish Parliament, and then each provincial quota was politically shared out between municipalities by provincial governors. It was only at municipal level where the already given amount of taxes to be paid was distributed among taxpayers according to the estimated cadastral value of their property and derived income (Carrasco, 1867). The Distribution of Personal Wealth in Real Estate Ownership clearly demonstrated that the tax burden applied to different municipalities of the Barcelona province in 1852 varied a lot, from twelve up to more than twenty per cent of the local aggregated income. Although some historians have used some partial information taken from these provincial lists (Díez Espinosa, 1986; Segura, 1993; Díaz Marín, 2000; Calatayud, Millán \& Romeo, 2000; Burgueño, 2007), this is the first time that a large dataset is created and fully analysed using the whole information they contain.

Unfortunately, this exceptional source also entails a very important ambiguity in the economic data provided. The primary information contained in the local amillaramientos referred to the surfaces of land owned by each taxpayer, together with their houses and livestock. Clearly, this was information on the distribution of agrarian wealth. Owing to other contemporary sources (Peña, 1852; Carrasco, 1867) we know the specific methods that had to be used by the Finance officials to estimate in money terms an average yearly 
income from the cadastral information on personal properties recorded in physical units. However, only these final cadastral estimates of annual incomes were published in the Distribution of Personal Wealth in Real Estate Ownership of 1852. This is understandable, considering the aim to assess the tax burden variation among different taxpayers and municipalities of the same province. But it requires us to deal with the resulting ambiguity: Are we calculating inequalities of wealth or income? It is well known that inequality of wealth is always greater than income inequality (Van Zanden, 1995). While people should at least be able to survive with the latter, real estate property was the result of a long-lasting accumulation that could only be carried out by those having higher incomes (Shenk et al., 2010).

Since only the cadastral estimated revenues from land, houses and livestock were included, we cannot take this income information as if it had recorded all sorts of agrarian earnings. In addition, this information on rural earnings was given by means of an estimated average income that any landowner or tenant could obtain yearly from their properties, according to the standardized procedures applied by the cadastral officials. Surprisingly enough, the Gini coefficients obtained from this indirect data on personal agrarian incomes are rather similar to the ones directly calculated from the distribution of landownership measured in surface units from the local amillaramientos. This coincidence might have something to do with the existence of proportionality between the distributions of wealth and rents paid for housing (Peña, 1852), in the same vein as some economists of the time had alleged in order to propose using the data on rental housing as an easy proxy for personal income (San Julián, 2011).

In any case, the way of accounting the estimated agrarian incomes and wealth introduces and important bias in our dataset. A relevant share of all taxpayers included in the lists had only a very poor house of their own. Their recorded incomes were the implicit rent that could have been obtained by leasing these poor houses in the market, after having deduced a quarter of the rent as repair costs. Some others could also be sharecroppers, either as rabassa winegrowing tenants living in a village or as sharecropping families who, according to another typical Catalan contract called masoveria, had to live in the farmhouse where they worked for the owner of the mas. In this case, the cadastral valuation had to include the sharecropper's net income, obtained by deducting from their annual earnings the rent paid to the landowner (Peña, 1852). It is far from certain, however, that this rule had been always followed in the local cadastral registers (amillaramientos) from where our data comes from.

The Distribution of Personal Wealth in Real Estate Ownership of 1852 includes a great deal of very poor taxpayers with only rather incomplete incomes, because they were be- 
low the lowest male agricultural wage at the time and no one could have survived with such a low yearly earning. According to the available series of Catalan agricultural wages for unskilled tasks, like digging, during the five years between 1850 and 1854 an agricultural labourer who worked 260 days a year would earn an income of some 1,720 Spanish reales in the province of Barcelona (Garrabou \& Tello, 2002). The urban planner Ildefons Cerdà calculated the prevailing family budgets in Barcelona at the time in around 6,622 reales for a full working-class family (Cerdà, 1867). This means that at least three to four male adult unskilled wages like the ones considered would have had to be added up in order to achieve the minimum standard of living calculated by Cerdà. The cost of living was cheaper outside Barcelona, but this data reveals that between 1,500 to 2,000 reales could be considered a minimum income to survive at the time. However, the list of taxpayers of 1852 included a lot of people below that level (see Table A1 in the Annex). An astonishing $84-87 \%$ appeared in the document with a cadastral attributed income under the abovementioned poverty line of 1,500-2,000 reales a year.

Although this $87 \%$ of people who had such a small property worth less than 2,000 reales a year only owned $27 \%$ of all income recorded, they actually paid $30 \%$ of all cadastral taxes collected in the province. If we set aside the outlier case of Barcelona city, in most rural municipalities the proportion of taxes paid by taxpayers with an attributed income lower than 2,000 reales ranged from 32 to $50 \%$. Even assuming that such poor taxpayers had endured exactly the same tax rate as the very rich, the prevailing tax system would have been very regressive. Our data show that they always bore an even higher tax burden (see Table A2 in the Annex). This clearly explains why the wealthy rural elites were so interested in including such a great amount of poor people in the taxpayers' list. In this way, the Spanish Treasure could raise a lot by extracting a bit from many taxpayers who only earned very little. Insofar as the tax quotas of each province and municipality came as given by previous political decisions taken top-down from the parliament and provincial governors, the relevant share paid by the poorest contributors became tax cuts for the local wealthy landowners.

While the vast majority of poor taxpayers were only attributed with cadastral earnings ranging from several tens to some hundreds of reales, and paid taxes for a few tens to less than a real per year, the small group of the richest taxpayers owned rural properties worth tens of thousands reales, and paid taxes for several thousand reales a year. In an electoral system based on the taxes paid, only major taxpayers were entitled to vote. We wonder whether the Spanish tax system described above might have something to do with the granting of voting rights to the entire adult male population as early as 1890; and also, consequently, with the immediate corruption of this general male suffrage by the so called Spanish caciquismo (Moreno Luzón, 2007). The anomalous tax system based on a po- 
litical top-down allocation of cadastral quotas established, in fact, a perverse rule of the game encouraging the creation of vertical lobbies to get the minimum local tax share to be paid to the Treasure, and receive the maximum public expenditure in each province and municipality (Curto-Grau, Herranz-Loncán \& Solé-Ollé, 2012).

In any case, the inclusion of so many people owning only a house, and perhaps a vegetable garden, together with landless tenants with very low yearly earnings, clearly biases our dataset. However, their presence also provides valuable information. We will later explain the adjustments we made to deal with these ambiguities in order to try to account for inequality in this agrarian income distribution. Before resuming with our analysis, we must finally refer to another concern raised by this kind of historical source. What credibility can we give to the information it contains, given the tax purpose of the document? Our research team has worked for many years using the private accounting records of the patrimony of the Marquis of Sentmenat, one of the richest Catalan landowners of the time. From his private records, we know that during the five years between 1850 and 1854 the Marquis earned in the two municipalities of Sentmenat and Palau-solità i Plegamans an actual average income of 12,047 and 15,983 reales a year respectively (Garrabou, Planas \& Saguer, 2001b). The Distribution of Personal Wealth in Real Estate Ownership of 1852 attributed to the Marquis of Sentmenat a yearly cadastral income of 11,607 and 15,323 reales in the same municipalities: this means a downward deviation of only $3.9 \%$. The comparison increased our trust in the accuracy of the information provided by this source.

\section{SEARCHING FOR INEQUALITY PATTERNS}

After mapping inequality indices, and unlike what happens with land-use spatial patterns (Garrabou et al., 2009: 156), no apparent coincidence seems to appear in the spatial distribution of the prevailing inequality of agrarian incomes earned from real estate ownership. Often, the differences between neighbouring municipalities located in the same zone of land-use specialization were as pronounced as the ones observed among the major boundaries between land use areas of winegrowing, cereal-cropping, and woodland (see Figure 1). 


\section{FIGURE 1}

Theil indices of inequality in the municipalities

of the province of Barcelona, 1852

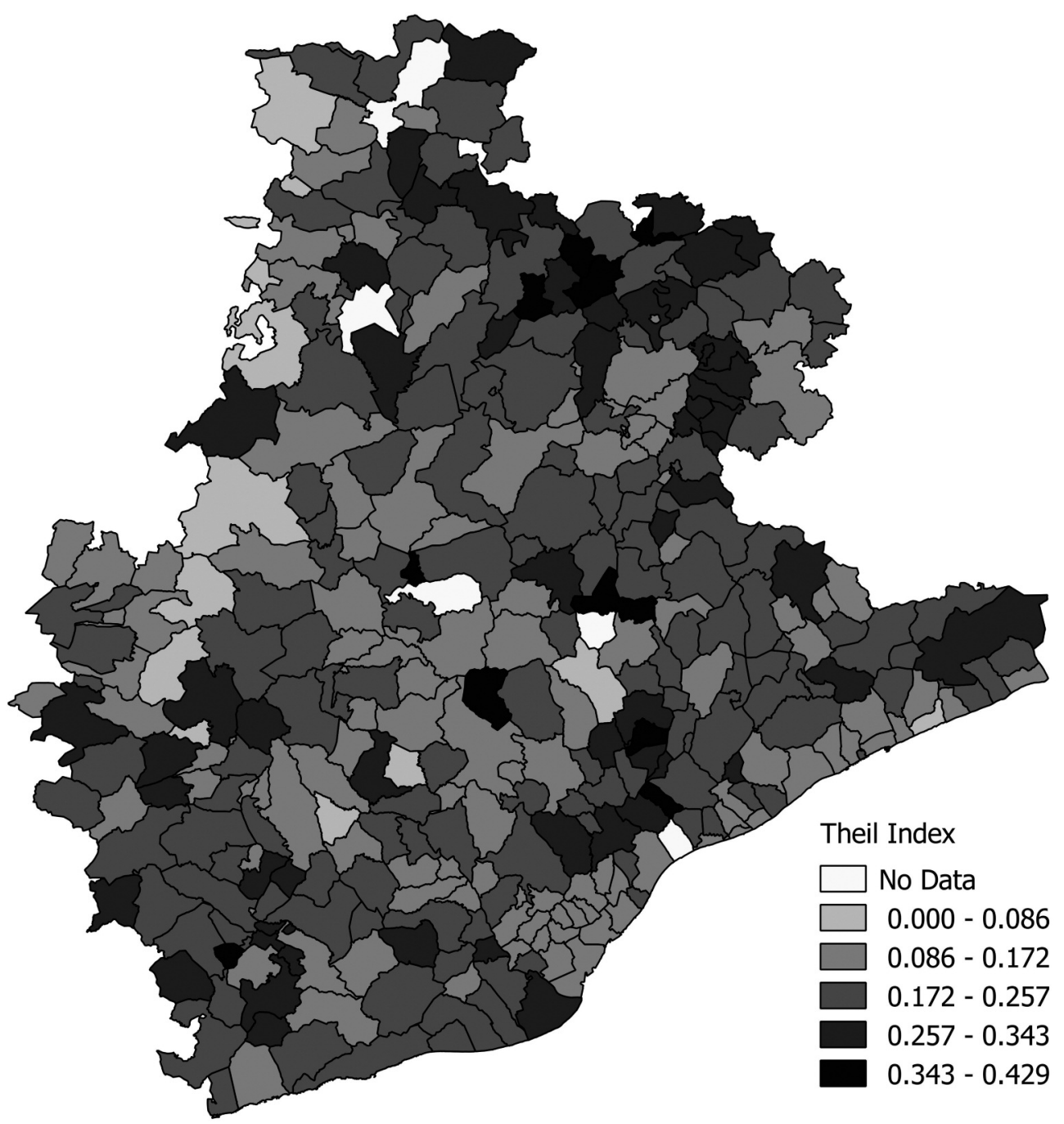

Source: our own, from the Distribution of Personal Wealth in Real Estate Ownership of 1852 (Library of the Universitat de Barcelona, reference 146-1-II/13).

Theil indices have been obtained from the dataset of income cadastral values recorded for every taxpayer included in each municipality (see the methodological supplementary material) in the following way: 


$$
\text { Theil }_{i, \text { Normalized }}=\frac{\text { Theil }_{i}}{\text { Theil }_{i, \operatorname{Max}}}=\frac{\frac{1}{N_{i}} \sum_{j} \frac{x_{i, j}}{\bar{x}_{i}} \ln \left(\frac{x_{i, j}}{\bar{x}_{i}}\right)}{\operatorname{Ln}\left(N_{i}\right)}
$$

where $N_{i}$ is the number of observations in each municipality $i, x_{i, j}$ each one of the individual observations of the annual incomes for every municipality, and $\bar{x}_{i}$ is the mean value of the distribution for each municipality. The Theil index shows less inequality as values tend to zero and more inequality as values tend to one. Theil values correct the potential bias attributable to the wide range of variation in the number of taxpayers and inhabitants in different municipalities. Table 1 shows the main statistics for the Theil index and other inequality indices.

\section{TABLE 1}

Main statistics for the various inequality index of the database on 1852 taxpayers in the municipalities of the province of Barcelona

\begin{tabular}{lrcr}
\hline & Theil & Mean log deviation & Gini \\
\hline Number & 292 & 292 & 292 \\
Mean & 0.202 & 1.016 & 0.668 \\
Standard deviation & 0.073 & 0.391 & 0.105 \\
Median & 0.201 & 0.958 & 0.682 \\
Max & 0.429 & 2.566 & 0.873 \\
Min & 0.018 & 0.071 & 0.193 \\
\hline
\end{tabular}

Source: our own, from the Distribution of Personal Wealth in Real Estate Ownership of 1852 (Library of the Universitat de Barcelona, reference 146-1-II/13).

TABLE 2

Comparison between the main statistics of the database on the number of taxpayers in 1852 and of inhabitants in 1857 in the municipalities of the province of Barcelona

\begin{tabular}{lcc}
\hline & Taxpayers in $\mathbf{1 8 5 2}$ & Inhabitants in $\mathbf{1 8 5 7}$ \\
\hline Maximum & 9,616 & 235,643 \\
Minimum & 17 & 211 \\
Mean & 297 & 2,396 \\
Median & 205 & 979 \\
\hline
\end{tabular}

Source: our own, from the Distribution of Personal Wealth in Real Estate Ownership of 1852 (Library of the Universitat de Barcelona, reference 146-1-II/13) and population census of 1857 (available at http://www.ced.uab.es/index.php?newlang=eng). 
The dispersion of Theil indices, and the existence of two peaks, lead us to seek for a few complementary explanations. As we have seen, our dataset is highly heterogeneous. For example, we find a maximum population of 235,643 inhabitants in the city of Barcelona, together with many municipalities having a minimum below 300 inhabitants. At the same time, some municipalities had an important percentage of taxpayers while in other cases the percentage was lower, thus indicating the necessity for a deeper statistical analysis (Table 2).

\section{TABLE 3}

Main characteristics of the groups resulting from the cluster analysis of the municipalities of the province of Barcelona, 1858

\begin{tabular}{lcccccc}
\hline Group & $\mathbf{N}$ & Density $\left(\mathbf{i n h a b} / \mathbf{k m}^{2}\right.$ ) & Vineyard & Forestry & Cereal & Distance to BCN (hour) \\
\hline 1 & 15 & Very high & Very high & Low & Low & Very near \\
2 & 30 & Average & Very high & Low & Low & Near \\
3 & 5 & Very high & High & Very Low & Very high & Very near \\
4 & 20 & Average & Low & Low & Very high & Average \\
5 & 8 & Very high & Average & Low & Very high & Near \\
6 & 20 & Low & Very low & Very high & Low & Very far \\
7 & 51 & Low & High & Average & Low & Near \\
8 & 37 & Low & Low & High & Low & Near \\
9 & 14 & Low & Very Low & High & High & Far \\
10 & 48 & Very low & Very low & High & Low & Far \\
11 & 26 & Average & Average & Average & High & Near \\
12 & 18 & Low & Very high & Very low & High & Average \\
$\mathrm{N}$ & 292 & 135.8 & $24.4 \%$ & $52.2 \%$ & $20.6 \%$ & 12.0 \\
\hline
\end{tabular}

Source: our own from Moreno Ramírez (2011 [1858]).

In order to check the relationship between Theil inequality indices and the main land use patterns of the municipalities, we have repeated the analysis of the basic statistics splitting these municipalities considering groups based on statistically rigorous thresholds. The dataset has been split off according to similarity criteria considering cluster analysis from the percentage of winegrowing and cereal-cropping over total agricultural land, forest area over the total area of each municipality, the population density and the distance to Barcelona. To do that we carried out a non-hierarchical clustering with the number of groups obtained from a hierarchical clustering estimation ${ }^{1}$. The information of municipal land uses has been taken from the 1858 Land-Use Statistics of the Province of

1. Considering Ward's linkage cluster analysis and assuming that we observe few changes when observing the Calinski-Harabasz pseudo-F coefficient after 12 groups. 
Barcelona compiled by Pedro Moreno Ramírez (2011[1858]). The resulting categories were 12. Table 3 summarizes the main characteristics of each group.

Figure 2 shows the differences in inequality indices (means) by groups, and their standard deviations, ordering the groups from lowest to highest inequality.

\section{FIGURE 2}

Theil indices by groups of the database on the number of taxpayers according to cluster land-use groups in the municipalities of the province of Barcelona, 1852-58

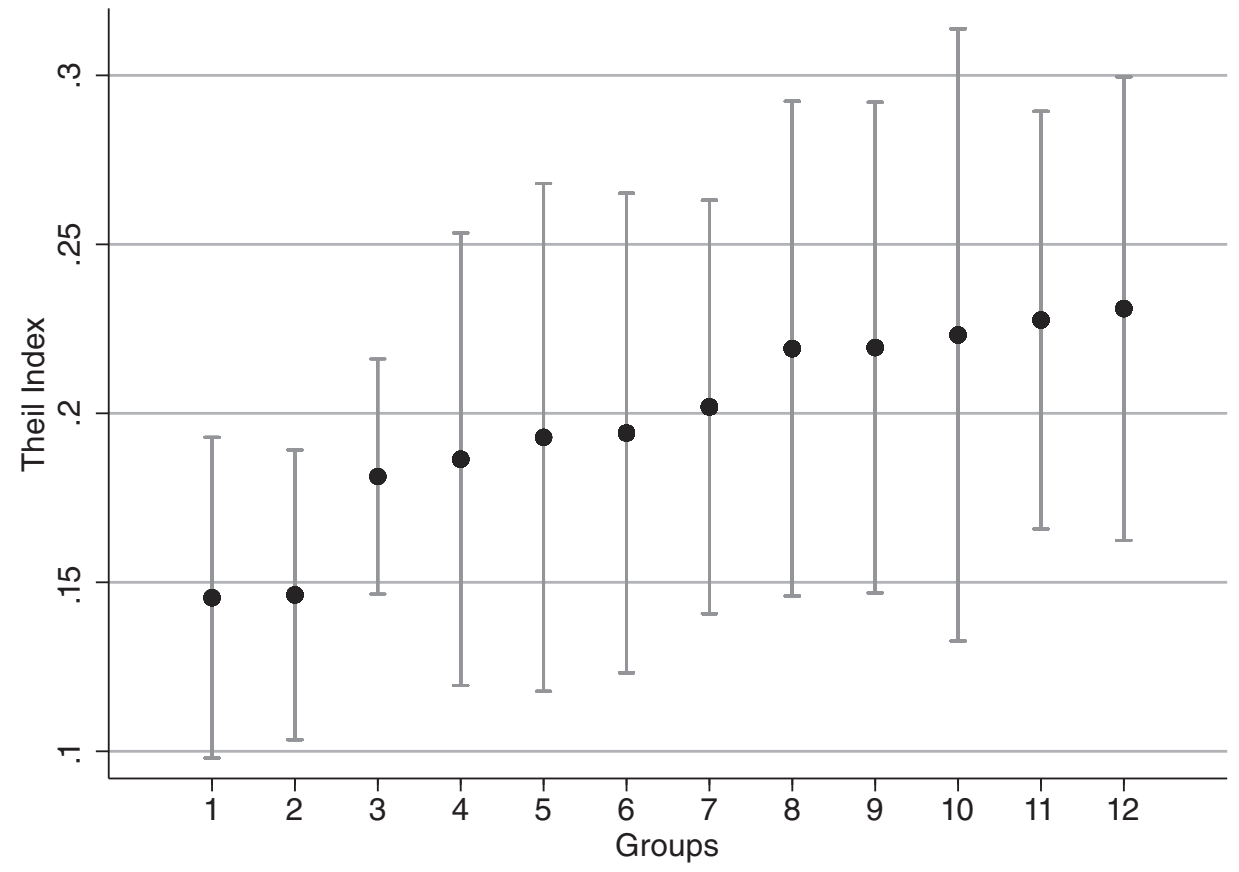

Source: our own, from the same historical sources referred in Figure 1 and Table 3.

According to Figure 2, the least unequal municipalities where those with a high share of vineyards, low share of forestry and cereal land, and close to Barcelona with either average population density (group 2) or high densities (group 1). Conversely, those more unequal municipalities had higher shares of cereal with low density (group 9 and 12), higher share of forestry with low density and low share of vineyards (group 8, 9 and 10), and high share of cereal land in municipalities close to Barcelona (group 11).

When comparing averages among groups we found the existence of statistical differences, specifically among group 1 and 2 in the one side and group 10, 11 and 12 on the 
other side ${ }^{2}$. Furthermore, distances among mean and median warns us about the likely existence of non-normal distributions in the dataset. This first outcome leads us to ask about the underlying reasons for the complex spatial inequality pattern found in the province of Barcelona in mid- $19^{\text {th }}$ century, and the best statistical way to deal with this. Taking into account the characteristics of the available information, and the abovementioned biases existing in the dataset, we can outline a list of five likely factors that may have obscured these initial results:

a) There were no large areas of monoculture in the province of Barcelona. Almost all municipalities combined different proportions of all land uses. The very different size of municipalities, and the absence of large flat areas, involved the existence of many contrasting realities in the land uses prevailing within each place. In particular, the larger and more populous municipalities always combined cereal crops in the flattest lands with forest uses in the more slopping ones, and vineyards planted in intermediate slopes. Thus, we have never a "pure" winegrowing municipality clearly detached from other totally devoted to cereal or forest uses.

b) As explained, the database includes only taxpayers who had some real estate of their own. That means excluding some people deprived of property who, in many cases, obtained most or all of their incomes through wages earned by working in agriculture. At the same time, however, the database includes a large proportion of taxpayers only owing a poor house and a small vegetable garden, or having a sharecropping contract. If a significant number of adults deprived of property were unevenly distributed between municipalities with different land usages, this may introduce another bias in our database.

c) The simultaneous presence of wealthy landowners and well-off peasants along with a high proportion of landless residents who only held a poor house with garden, or could rely on sharecropping contracts, involves mixing very different realities in the same database. The resulting distribution seems to move in different orders of magnitude. As explained, this is largely the outcome of ambiguous data which is halfway between a distribution of land ownership and a distribution of agrarian income. To make it more coherent, either all types of income are included in the database or all attributed cadastral earnings should be converted into the original valuation of real estate property.

2. An ANOVA test shows a F-statistics $=4.20$ and $p=0.001<0.05$ accepting the existence of differences among means. 
d) The municipalities were not only very different in size, but also in population and wealth. As population density increased, so did the number of residents who made their living with activities that had little or nothing to do with land and livestock ownership. In this point, the contrast between rural towns, villages and the city matters. Barcelona becomes a special case that for our purpose has to be set aside as an outlier.

e) Inequality in the distribution of agrarian incomes within each municipality also depended on its level of wealth. Poorer areas could have lower inequality indices just because people had to achieve at least a subsistence minimum. However, the frontier of maximum inequality rose along with the wealth of a rural community. Consequently, the comparisons of inequality between municipalities should take into account their respective levels of the inequality possible frontier (IPF) and Inequality Extraction Ratio (IER).

In order to solve these difficulties, and improve our quantitative analysis, we will undertake in the next sections a deeper analysis of rural income inequality by including a level of subsistence income, using the frontier of maximum inequality linked to the wealth of each community (IPF), and comparing it with the inequality registered (IER).

\section{A DEEPER ANALYSIS OF AGRARIAN INCOME INEQUALITY}

Now we will try to deal with the double bias encountered, due to the fact that the original dataset only includes taxpayers, not the entire rural population who earned incomes from agrarian activities; and also, that many of these taxpayers appear with implausible incomes below the minimum subsistence level. The first bias reduces and the second one increases the inequality level, and without knowing their relative weight we cannot guess how they may skew the results obtained from this database. To correct the first bias, we have subtracted from the population figures in the census of 1857 the number of owners included in the lists of taxpayers of 1852 , in order to then add to the original database the adult male population without any land, house or cattle of their own. They will be taken as a zero group in the valuation of property in each municipality. Afterwards, so as to turn the ambiguous dataset on personal wealth into a clearer distribution of agrarian incomes, we have added a minimum vital income of 1,500 reales a year -considered to be obtained from wages or earnings other than land, housing and livestock rents- to the earning valuation of property held by all inhabitants included in the new dataset. As explained, this flat vital income is obtained considering the unskilled daily wage of a Catalan labourer at the time multiplied by 260 working days a year (see the methodological supplementary material). 
Unfortunately, these two changes will entail some disadvantages as well. The major drawback is that all inequality levels resulting from the new dataset are lower than the original ones, as expected. Taking this strong shift towards a more even distribution into account, from now on we can only consider significant the relative differences between the new Theil indices obtained in each municipality, not their absolute values. The key question is how different the new distributions are from the previous ones obtained with only taxpayers.

\section{FIGURE 3}

Theil indices of the corrected sample from the original dataset, according to cluster land-use groups of the municipalities in the province of Barcelona, 1852-58

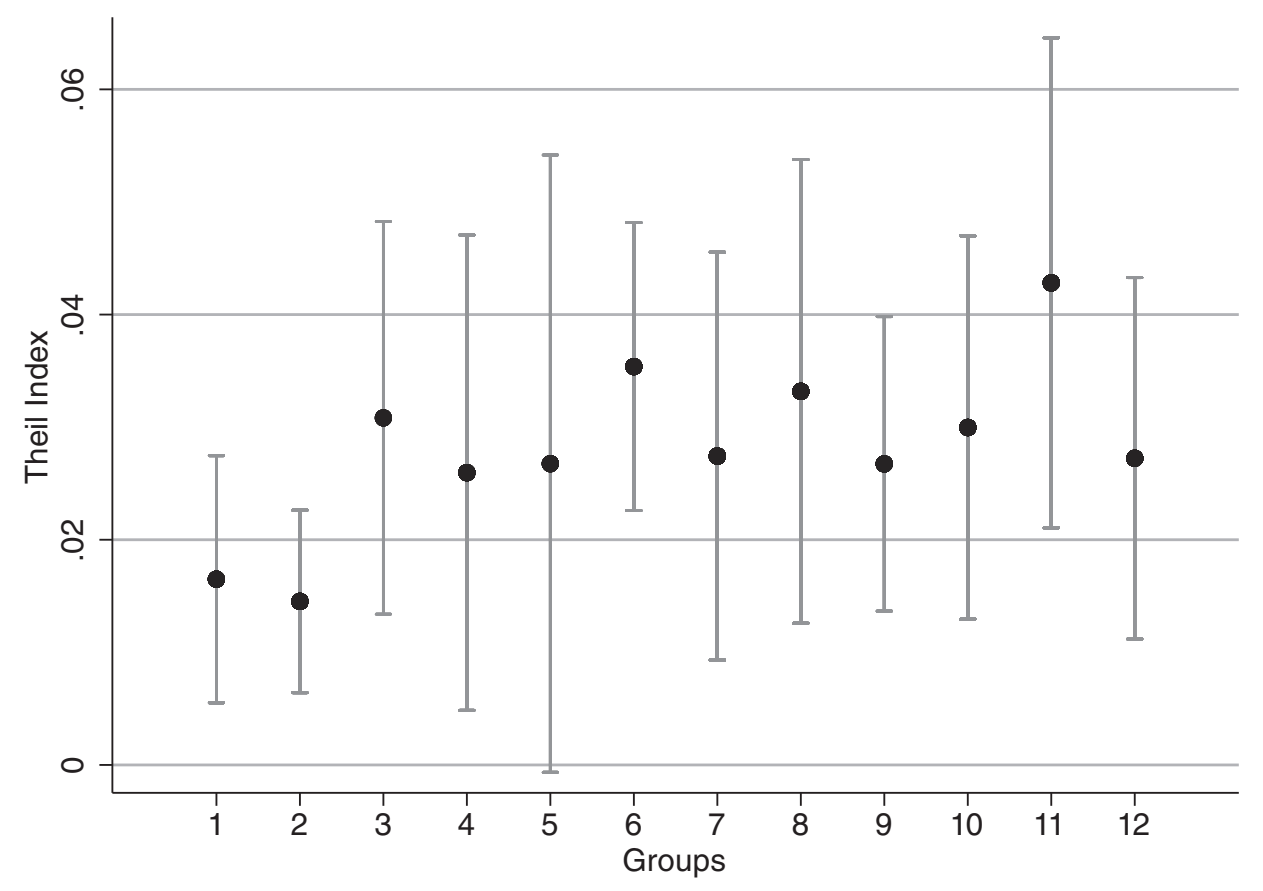

Source: our own, from the same historical sources referred in Figure 1 and Table 3.

In Figure 3 we see that group 1 and 2 remained as the least unequal municipalities. The correction increases inequality in group 6 (with high share of forest, low population density and far from Barcelona), reinforces inequality in group 11 (high share of cereal and close to Barcelona), and reduces inequality in other groups with a high share of vineyards: 1,2 and 12 (the latter being the most unequal in the non-corrected sample). Differences on means by different groups remained statically significant. It is clear that the omission of non-taxpayers overestimated inequality levels in those municipalities with a high share 
of vineyards, and underestimated inequality levels in those municipalities with a high share of forestland and low population densities.

\section{ESTABLISHING THE INEQUALITY POSSIBILITY FRONTIER (IPF) AND INEQUALITY EXTRACTION RATIO (IER)}

After having incorporated the previous corrections and caveats in the calculation of Theil indices, now we have to face the most difficult task. How the lack of a clear spatial pattern found when comparing the land-use maps with inequality of rural income distribution can be overcome? It seems as if there was a greater historical contingency in the geographical patterns of agrarian income inequality (Figure 1) than in the geographical distribution of prevailing land uses (Garrabou et al., 2009: 156). This might be due to diverging local paths. While the landowners of a municipality could have decided to keep their forest and pasture lands exploited in a traditional manner, raising livestock and selling timber, firewood or charcoal, others might have chosen to establish a great deal of rabass a tenants in them who transformed the same sorts of land into vineyards. These different occasional decisions could have reinforced themselves over time in neighbouring areas, leading through path dependence and self-reinforcing trends to contrasting spatial realities juxtaposed into the same territory.

The main question that arises is whether we can find or not some key omitted variables which could capture and explain a great deal of this historical contingency. An important side of the question is that once the landowners of a place had decided to offer or not an opportunity to establish immigrants or disinherited people as winegrowing tenants in their lands, this would have entailed consequences for population sizes and levels of wealth in each community as well. If there was any relationship between the level of agrarian income inequality and the increase of wealth attained through a high investment in land improvement in a rural community, this could provide an interesting way to capture the disturbing degree of local contingency we found. This is why we decided to account for the inequality possibility frontier (thereinafter, IPF) that depends upon the level of economic development and agrarian wealth, as put forward by Milanovic, Lindert and Williamson (2011). When the wealth of a community increases so does the IPF, which may generate a greater distance between the vast majorities kept at subsistence level and a tiny elite able to concentrate the rest of income.

Therefore, we are going to use the IPF in order to calculate new inequality indices of personal agrarian income adjusted to different levels of rural wealth (see the methodological supplementary material). The first step is to work out the maximum values of in- 
come inequality in each municipality. Following Milanovic, Lindert and Williamson (2011), the average income of the elite is:

$$
Y \varepsilon_{i}=\frac{T I_{i}-\left(N_{i}-\varepsilon_{i}\right) * \mu_{s}}{\varepsilon_{i}}=\frac{1}{\varepsilon_{i}}\left[T I_{i}-\left(N_{i}-\varepsilon_{i}\right) * \mu_{s}\right]
$$

where $Y \varepsilon_{i}$ is the average income of the elite in a municipality $i, T I_{i}$ is the total income in each municipality, $\mu_{s}$ is the subsistence income in each municipality, $N_{i}$ is the total adult male population and $\varepsilon_{i}$ is the number of persons that represents the elite also in this municipality.

To obtain the Theil index for the IPF ( $\mathrm{T}^{*}$ ) of each municipality, we consider equation (1). The local population is divided into two groups, the first one with the subsistence income $\left(\mu_{s}\right)$ and the other with the income of the elite that obtains the rest of the surplus of the municipality, as shown in equation (3).

$$
\begin{aligned}
T_{i}^{*}=\frac{1}{N_{i}} \sum_{j} \frac{x_{i, j}}{\bar{x}_{\imath}} & \\
& =\frac{1}{N_{i}}\left[\left(N_{i}-\varepsilon_{i}\right) \frac{\mu_{s}}{\mu_{i}} \ln \left(\frac{\mu_{s}}{\mu_{i}}\right)\right. \\
& \left.+\varepsilon_{i} \frac{\frac{1}{\varepsilon_{i}}\left[T I_{i}-\left(N_{i}-\varepsilon_{i}\right) * \mu_{s}\right]}{\mu_{i}} \ln \left(\frac{\frac{1}{\varepsilon_{i}}\left[T I_{i}-\left(N_{i}-\varepsilon_{i}\right) * \mu_{s}\right]}{\mu_{i}}\right)\right)
\end{aligned}
$$

Lastly, to make comparable this index with the rest of the values obtained for the entire dataset we have normalized equation (3) dividing by $\ln \left(N_{i}\right)$. From the calculus of the $\mathrm{T}^{*}$ normalized we can obtain the inequality extraction ratio (IER thereinafter) for each municipality, considering:

$$
I E R_{i}=\frac{\text { Theil }_{\text {Norm }, i}}{T_{\text {Norm }, i}^{*}}
$$

IER indicates the percentage of the inequality that existed in each municipality respect to the IPF, which is the maximum potential of inequality possible with a defined value 
for $\varepsilon_{i}$, assuming $\varepsilon=1$ (the elite is formed by one person), $N_{i}$ is the value of the adult male population of the municipality. When $\mathrm{ER} \rightarrow 0$ the value indicates that the level of inequality registered in the municipality was well below the potential frontier of maximum value of inequality. In the other extreme, when $\mathrm{ER} \rightarrow 100 \%$ the level of inequality obtained is close to the level of maximum potential inequality. The results can be observed in Figure 4 .

\section{FIGURE 4}

Inequality Extration Ration (IER) according to cluster land-use groups, population densities and other features in the municipalities of the province of Barcelona, 1852-58

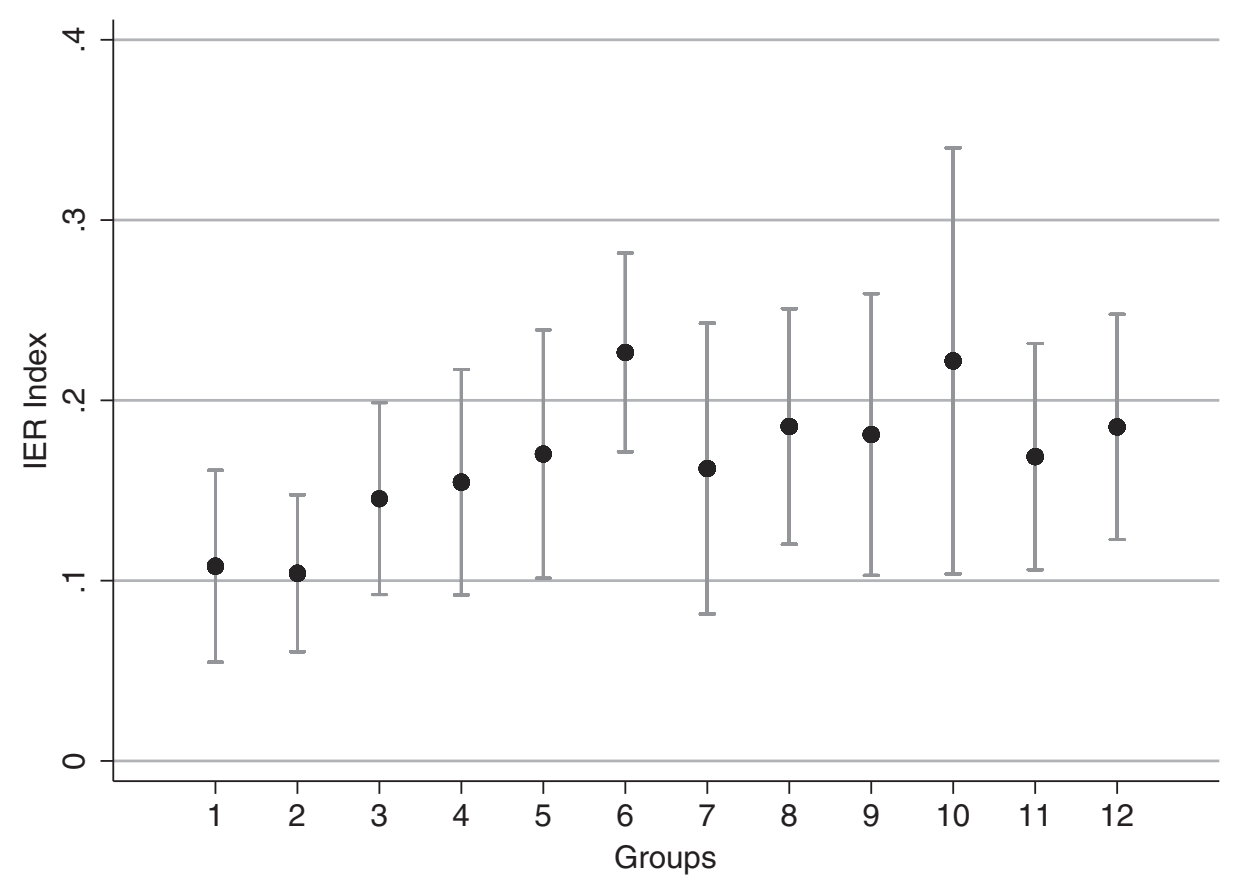

Theil $1_{\mathrm{IPF}}$ indices of each municipality have been calculated considering the elite $=1$.

Source: our own, from the same historical sources referred in Figure 1 and Table 3.

Figure 4 and the summary of Table 4 confirm many of the previously reported results, adding at the same time a novel perspective. Winegrowing municipalities near to Barcelona (group 1 and 2) were further away from potential levels of inequality, while municipalities with mainly forestland, low population densities and far from Barcelona (group 6 and 10) were closer to their maximum IPF. Another interesting result is that IER figures for cereal crop municipalities near to Barcelona (group 11 and 12) now appear around the mean, whereas former Theil values had shown higher inequality (both for corrected and non-corrected estimations). 
These changes in the ranks and levels of municipal inequality highlight the importance of introducing the corrections considered in the dataset so as to obtain more revealing results. As can be seen, the figures for the other groups remained stable with non-significant changes between IER and the former figures. ANOVA test confirms the existence of statistical differences between the means of the groups in both extremes, that is group 2 as being the least unequal municipalities and group 6 and 10 as being the most unequal municipalities $(\mathrm{F}=43.0)$.

\section{TABLE 4}

Extraction ratio (IER), Theil and Theil corrected with income of non-taxpayers, according to cluster land-use groups, population densities and other features in the municipalities of the province of Barcelona, 1852-58

\begin{tabular}{lrcrrrr}
\hline \multicolumn{5}{c}{ Absolute values } & \multicolumn{3}{c}{ Mean $=\mathbf{1 0 0}$} \\
& Theil & Theil - corrected & IER & Theil & Theil - corrected & IER \\
\hline 1 & 0.15 & 0.02 & 0.11 & 72.2 & 57.9 & 62.4 \\
2 & 0.15 & 0.01 & 0.10 & 72.6 & 51.0 & 60.1 \\
3 & 0.18 & 0.03 & 0.15 & 89.9 & 108.2 & 84.0 \\
4 & 0.19 & 0.03 & 0.15 & 92.5 & 91.1 & 89.3 \\
5 & 0.19 & 0.03 & 0.17 & 95.7 & 93.9 & 98.3 \\
6 & 0.19 & 0.04 & 0.23 & 96.3 & 124.2 & 130.8 \\
7 & 0.20 & 0.03 & 0.16 & 100.2 & 96.3 & 93.7 \\
8 & 0.22 & 0.03 & 0.19 & 108.7 & 116.4 & 107.1 \\
9 & 0.22 & 0.03 & 0.18 & 108.9 & 93.8 & 104.5 \\
10 & 0.22 & 0.03 & 0.22 & 110.7 & 105.2 & 128.1 \\
11 & 0.23 & 0.04 & 0.17 & 112.9 & 150.2 & 97.5 \\
12 & 0.23 & 0.03 & 0.19 & 114.6 & 95.6 & 107.0 \\
\hline Average & 0.20 & 0.03 & 0.17 & & & \\
\hline
\end{tabular}

Source: our own, from the same historical sources referred in Figure 1 and Table 2.

It is important to point out that this happens in spite of the fact of having previously included in our database a flat vital minimum income for all male adults, which inevitably entailed a compression of all Theil indices around very low absolute values of income inequality. The differences found become much more relevant when the abovementioned bias is taken into account, allowing us to confirm that the study of income inequality using the IER approach is able to reveal some important hidden dimensions of the question.

Table 4 summarizes the main results found with this statistical corrections and novel methodological approaches. They confirm that, before the Phylloxera plague, vineyard spe- 
cialization was mainly performed in the province of Barcelona by poor landless peasants who sought to earn their living working as emphyteutic tenants on the thin and sloping soils leased to them by landowners. Nevertheless, this commercial specialization played a key role by linking the area with the emerging Atlantic economies, and gave way to an increase in population densities near the level of an urban-industrial society (Badia-Miró et al., 2010; Badia-Miró \& Tello, 2014). These figures also uphold our initial hypothesis that agrarian income inequality was kept lower in municipalities where vine-growing was carried out mixed with some degree of cereal cropping and forestry uses. This reduction in income inequality took place notwithstanding the land improvements made by these poor winegrowers, which increased the wealth of the whole rural community thus enhancing the frontier of a possible maximum inequality (IPF).

Indeed, the hard work of terracing poor sloping soils and planting vineyards was a huge investment in land improvement (Olarieta, Rodríguez \& Tello, 2008) which increased the wealth of the entire rural community. How can this be reconciled with the fact that average income in winegrowing municipalities (group 1 and 2) appears to be the lowest in Table 5? The distinction between agricultural income averages per person or unit of land becomes a key issue here (see also Table 6 of the methodological supplementary material). As can be seen in Table 5, income per unit of land was higher in winegrowing municipalities than in forestry areas or cereal zones. Nevertheless, per capita averages were lower in the former than the latter.

Catalan vineyards were either spread over former forest and brushwood lands, or replaced poor intercropped cereal lands previously sown within sparse rows of vines and olive trees. The right columns in Table 5 clearly confirm that vineyard specialization enhanced the wealth of land -or the landesque capital in the term put forward by Amartya Sen (1959) and Håkkanson and Widgren (2014). However, left columns highlight that vineyards also required higher labour intensity, and this increased population densities even more. Therefore per capita levels of agricultural income and wealth became the lowest, besides being more evenly distributed.

This feature coincides with the estimates made in mid- $18^{\text {th }}$ century France by François Quesnay, who also attributed to the winegrowing peasant-owners the lowest non-wage agricultural income in his Tableau Économique and other writings (Milanovic, 2010). However, French winegrowers were mainly property-holders -exactly the same status that Catalan rabassa tenants aimed to earn some day through their collective struggle. Compared with their French counterparts, the Catalan winegrowing emphyteutic tenants could only be considered as would-be peasants. Nevertheless, their legal and actual status was also clearly stronger than many other tenants-at-will, or labour-tenants, that existed in sev- 
eral regions of Europe at the time, such as the statartorpare in Sweden, husmennene in Norway, husmaendene in Denmark, or heuerlinge in Northwestern Germany (Morner, 1970). Unlike the German heuerlinge-system (Schlumbohm, 1996), for example, that left the disinherited layers of the rural society at the mercy of landowners' will, the Catalan rabassa winegrowers were entitled with a temporary ownership over the vines they had planted as long as they were kept alive (Giralt, 1965; Balcells, 1980; Carmona \& Simpson, 1999; Simpson, 2011; Colomé, 2013; Colomé, Planas \& Valls-Junyent, 2015; Garrido, 2017a, 2017b, 2017c).

\section{TABLE 5}

Average income per person and unit of agricultural land in Spanish reales, according to cluster land-use groups and population in the municipalities of the province of Barcelona, 1852-58

\begin{tabular}{lrrrcc}
\hline Group & $\mathbf{N}$ & Mean Income & Mean Income corrected & Income / ha & Income corrected / ha \\
\hline 1 & 15 & 857.7 & $1,916.7$ & 819.9 & $3,483.4$ \\
2 & 30 & 631.9 & $1,933.9$ & 163.1 & 849.6 \\
3 & 5 & $1,010.8$ & $2,172.7$ & 333.0 & $1,064.1$ \\
4 & 20 & 991.0 & $1,985.3$ & 333.0 & $1,789.2$ \\
5 & 8 & $1,363.9$ & $1,945.9$ & 632.4 & $3,065.8$ \\
6 & 20 & $1,984.6$ & $2,033.5$ & 43.2 & 175.3 \\
7 & 51 & $1,009.3$ & $2,038.0$ & 87.9 & 362.8 \\
8 & 37 & $1,214.8$ & $2,080.9$ & 50.4 & 191.2 \\
9 & 14 & $1,111.1$ & $2,026.4$ & 64.6 & 269.0 \\
10 & 48 & $1,441.0$ & $1,996.0$ & 43.6 & 213.3 \\
11 & 26 & $1,078.8$ & $2,370.4$ & 203.5 & 613.6 \\
12 & 18 & 869.4 & $1,987.6$ & 192.4 & 897.8 \\
\hline Total & 292 & $1,144.4$ & $2,043.7$ & 169.7 & 748.5 \\
\hline
\end{tabular}

Source: our own, from the same historical sources referred in Figure 1 and Table 2.

During the $19^{\text {th }}$ century many precarious heuerling-tenants emigrated from North-western Germany to the United States, while most Catalan rabassa-sharecroppers fiercely fought with the landowners to stay in the land and become wholly owners of it. In Albert Hirschman terms, the former had to take the "exit" option while the latter could raise their "voice" to organize collective action (Hirschman, 1970). By transforming into vineyards a previous landscape of brushwood, forest and poor cereal crops, these rabassa tenants not only opened a room for themselves among the Catalan rural communities. They also gained a place in society and a share of its income (Garrabou, Tello \& Cussó, 2008; Garrabou et al., 2009). By increasing population numbers and deepening the home market, this eventually helped to turn Catalonia into a late-modern industrious society 
(Vries, 2010; Marfany, 2012) and an early-contemporary industrial economy (Valls-Junyent, 2004; Badia-Miró \& Tello, 2014).

\section{CONCLUSIONS}

Despite the initial high degree of contingency found in the spatial location of Theil indices (Figure 1), and the lack of a simple correlation between inequality indices and other variables tested, we have found some relevant land-use patterns of inequality in personal agrarian wealth or income distribution in the municipalities of the Barcelona province in mid$19^{\text {th }}$ century. These land-use profiles of agrarian income inequality have been confirmed and enhanced by correcting Theil indices of estimated income distribution for all the male adult population, and applying the inequality possible frontier (IPF) approach to compare the Inequality Extraction ratio (IER) with the maximum attainable one.

The corrected results confirm that agrarian income inequality was lower in winegrowing municipalities while, at the same time, underline the higher inequality of those mainly forestry municipalities that were on average already apparent before the correction of the sample and the introduction of the IER index. Those mainly forestry municipalities where the more unequal, and the highly populated winegrowing ones were the least in spite of attaining higher population densities, developing a commercial vineyard specialization, and increasing the total wealth above a subsistence line could have also meant an extended frontier (IPF) of possible inequality through a greater extraction ratio (IER) exerted by an agrarian elite. This outcome can be interpreted as a historical process of socioeconomic and political empowerment achieved by the Catalan rural class of winegrowing tenants thanks to the long-lasting social fight they waged from the $18^{\text {th }}$ century up to the outbreak of Spanish Civil war in 1936 (Badia-Miró \& Tello, 2014; Tello \& Badia-Miró, 2015; Colomé et al., 2016).

In this sense, the statistical cross-section analysis conducted with a remarkably large database of more than 86,000 recorded taxpayers in 292 municipalities has provided for the first time solid quantitative answers to a set of questions posed for a long time by Catalan rural historians. Our results also reinforce the ideas of those who argue that, beyond the undeniable impact of purely economic factors, the historical path followed by wealth and income distribution moves between greater degrees of freedom under a strong influence of many social, cultural and political forces (Atkinson \& Piketty, 2007). As Paul Krugman (2009) or Joseph Stiglitz (2012) have pointed out, changes in social values, political regulations, institutions and politics matter (Garrabou, Ramon-Muñoz \& Tello, 2015). 


\section{ACKNOWLEDGMENTS}

This work has been supported by the international Partnership Grant SSHRC-895-20111020 on 'Sustainable farm systems: long-term socio-ecological metabolism in western agriculture' funded by the Social Sciences and Humanities Research Council of Canada, the Catalan Government (2017SGR1466) at the Centre d'Estudis "Antoni de Capmany" d'Economia i Història Econòmica, and the Spanish research project HAR2015-69620C2-1-P. Marc Badia-Miró also acknowledges the support provided by the Spanish research project ECO2015-65049-C2-2-P.We are also very gratefully to the comments provided by Josep Colomé, Samuel Garrido, Jordi Planas, Raimon Soler, and the reports of three anonymous referees of Historia Agraria. We would also like to thank all the comments, criticisms and suggestions of our colleague and friend Francesc Valls-Junyent, who made great historiographical contributions to this topic and passed away recently.

\section{REFERENCES}

Acemoglu, D. \& Robinson, J. A. (2006). Economic Origins of Dictatorship and Democracy. Cambridge: Cambridge University Press.

Acemoglu, D., Robinson, J. A. \& Johnson, S. (2002). Reversal of Fortune: Geography and Institution in the Making of the Modern World Income Distribution. The Quarterly fournal of Economics, 117 (4), 1231-94.

Atkinson, A. B. \& Piketty, T. (2007). Top Incomes over the Twentieth Century: A Contrast between Continental European and English-Speaking Countries. Oxford: Oxford University Press.

Badia-Miró, M., Pinilla, V. \& Willebald, H. (Eds.) (2015). Natural Resources and Economic Growth: Learning from History? Abingdon: Routledge.

BAdiA-Miró, M. \& Tello, E. (2014).Vine-Growing in Catalonia:The Main Agricultural Change underlying the Earliest Industrialization in Mediterranean Europe (17201939). European Review of Economic History, 18 (2), 203-26.

Badia-Miró, M., Tello, E., Garrabou, R. \& Valls-Junyent, F. (2010). The Grape Phylloxera Plague as a Natural Experiment:The Upkeep ofVineyards in Catalonia (Spain), 1858-1935. Australian Economic History Review, 50 (1), 39-61.

Balcells, A. (1980). El problema agrario en Cataluña: La cuestión Rabassaire (18901936). Madrid: Ministerio de Agricultura, Pesca y Alimentación.

Bourguignon, F. \& Morrisson, C. (2002). The Size Distribution of Income among World Citizens: 1820-1990. American Economic Review, (92), 727-44.

Bravo, J. (1852). Real Orden de 10 de febrero de 1852 firmada por el Director General de Contribuciones Directas, Estadísticas y Fincas del Estado. Gaceta de Madrid, (2-3). 
BurgueÑo, J. (2007). Cartografia cadastral de la provincia de Lleida (segles XVIII-XIX). In INSTITUT CARTOGRÀFIC DE CATALUNYA (Ed.), La cartografia cadastral a Espanya (segles XVIII-XX) (pp. 39-49). Barcelona: Generalitat de Catalunya.

Calatayud, S., Millán, J. \& Romeo, M. C. (2000). El rentismo nobiliario en la agricultura valenciana del siglo XIX. Revista de Historia Económica-fournal of Iberian and Latin American Economic History, 18 (1), 79-107.

CARmona, J. \& Simpson, J. (1999). The "Rabassa Morta" in Catalan Viticulture:The Rise and Decline of a Long-Term Sharecropping Contract, 1670s-1920s. The Fournal of Economic History, 59 (2), 290-315.

Carrasco, P. A. (1867). Tratado de las contribuciones directas de España. Madrid: Establecimiento Tipográfico de T. Fontanet.

CERDÀ, I. (1867). Teoría general de la urbanización y aplicación de sus principios y doctrinas a la reforma y ensanche de Barcelona. Madrid: Imprenta Española.

Colomé, J. (2013). L'ofensiva dels propietaris contra el contracte de rabassa morta a la comarca del Penedès, 1850-1910. Recerques: Història, Economia, Cultura, (67), 11540.

Colomé, J., Cucurella, M. \& Valls-Junyent, F. (2010). Poblament i despoblament a la Catalunya vitícola (1760-1910). Butlletí de la Societat Catalana d'Estudis Històrics, (21), 137-55.

Colomé, J., García, R., Planas, J. \& Valls-Junyent, F. (2013). Les cycles de l'économie viticole en Catalogne: L'évolution du prix du vin entre 1680 et 1935. Annales du Midi: Revue de la France méridionale, (281), 29-55.

Colomé, J., Planas, J., Soler-Becerro, R. \& Valls-Junyent, F. (2016). The Rabassaire Struggle: Long-Term Analysis of a Social and Political Movement. International Review of Social History (63), 1-27.

Colomé, J. \& VAlls-JunYenT, F. (2012). Las consecuencias demográficas de la crisis filoxérica en la región vitícola del Penedés (Cataluña). Historia Agraria, (57), 47-77.

Colomé, J., Planas, J. \& VAlls-JunYent, F. (Eds.) (2015). Vinyes, vins i cooperativisme vitivinicola a Catalunya. Barcelona: Publicacions de l'Abadia de Montserrat.

Congost, R. (Ed.) (2015). The Catalan Mas: Origins, Transformations and the End of an Agrarian System. Girona: Associació d'Història Rural, Centre de Recerca d'Història Rural.

Curto-Grau, M., Herranz-Loncán, A. \& Solé-Ollé, A. (2012). Pork-Barrel Politics in Semi-Democracies: The Spanish "Parliamentary Roads", 1880-1914. The fournal of Economic History, 72 (3), 771-96.

DíaZ MARÍN, P. (2000). Oligarquía y fiscalidad: Los primeros pasos de la contribución de inmuebles, cultivo y ganadería en la provincia de Alicante. Revista de Historia Económica-fournal of Iberian and Latin American Economic History, 18 (2), 309-38. DíEz Espinosa, J. R. (1986). Desamortización y economía agraria castellana:Valladolid, 
1855-1868. Valladolid: Diputación Provincial/Institución Cultural Simancas.

Garrabou, R., Planas, J. \& Saguer, E. (2001a). Sharecropping and the Management of Large Rural Estates in Catalonia, 1850-1950. The Fournal of Peasant Studies, 28 (3), 89-108.

Garrabou, R., Planas, J. \& Saguer, E. (2001b). Un capitalisme impossible?: La gestió de la gran propietat agrària a la Catalunya contemporània. Vic: Eumo/Universitat de Vic.

Garrabou, R., Ramon-MuÑoz, J. M. \& Tello, E. (2015). Organització social del treball, salaris i mercat laboral a Catalunya: El cas d'una explotació agrària de la comarca de la Segarra a la darreria del segle XIX. Recerques, (70), 83-123.

Garrabou, R. \& Tello, E. (2002). Salario como coste, salario como ingreso: El precio de los jornales agrícolas en la Cataluña contemporánea (1727-1930). In J. M. MARTínez CARRIÓN (Ed.), El nivel de vida en la España rural, siglos XVIII-XX (pp. 17376). San Vicente del Raspeig: Universidad de Alicante.

Garrabou, R., Tello, E. \& Cussó, X. (2008). El cambio de usos del suelo en la comarca del Vallès (1850-2000): Fuerzas motoras y agentes rectores de la transformación del territorio. In R. GARRABOU \& J. M. NAREDO (Eds.), El paisaje en perspectiva histórica: Formación y transformación del paisaje en el mundo mediterráneo (pp. 233-58). Zaragoza: Prensas Universitarias de Zaragoza.

Garrabou, R., Tello, E., Cussó, X. \& Badia-Miró, M. (2009). Explaining Agrarian Specialization in an Advanced Organic Economy: Cereal Production, Consumption and Trade in the Province of Barcelona (Spain) in the mid-19 ${ }^{\text {th }}$ Century. In V. PINILLA (Ed.), Markets and Agricultural Change in Europe from the 13th to the 20th Century (pp. 137-72). Turnhout: Brepols.

GARRIDO, S. (2017a). ¿Desnaturalizados "rabassers"? La "rabassa morta" catalana antes de la filoxera. Ayer, (107), 155-82.

GARRIDO, S. (2017b). Sharecropping was sometimes Efficient: Sharecropping with Compensation for Improvements in European Viticulture. The Economic History Review, 70 (3), 977-1003.

GARRIDO, S. (2017c). El fruto de la inseguridad. Vino, contrato óptimo y derechos de propiedad en Cataluña. Revista de Historia Económica - Fournal of Iberian and Latin American Economic History, 35 (3), 415-43.

GIRALt, E. (1965). El conflicto "rabassaire" y la cuestión agraria en Cataluña hasta 1936. Revista de Trabajo, (7), 51-72.

Greasley, D., Inwood, K. \& Singleton, J. (2007). Factor Prices and Income Distribution in Less Industrialised Economies 1870-1939. Australian Economic History Review, 47 (1), 1-5.

HÅKKANSON, N. T. \& Widgren, M. (Eds.) (2014). Landesque Capital:The Historical Ecology of Enduring Landscape Modifications. London: Routledge. 
HaRLey, K. (2007). Comments on Factor Prices and Income Distribution in Less Industrialised Economies, 1870-1939: Refocusing on the Frontier. Australian Economic History Review, 47 (3), 238-48.

Hirschman, A. O. (1970). Exit, Voice, and Loyalty: Responses to decline in Firms, Organizations, and States. Cambridge: Harvard University Press.

Hornborg, A., McNeill, J. R. \& MARTíNez Alier, J. (2007). Rethinking Environmental History: World-System History and Global Environmental Change. Lanham: Altamira Press.

KRugman, P. (2009). The Conscience of a Liberal. New York:W.W. Norton \& Company. Lindert, P. H. \& Williamson, J. G. (2003). Does Globalization Make the World More Unequal? In M. D. Bordo, A. M. TAYLOR \& J. G. Williamson (Eds.), Globalization in Historical Perspective (pp. 227-71). Chicago: Chicago University Press.

López Estudillo, A. (2016). Cambio agrario, transformaciones sociales y desigualdades en dos municipios vitícolas delVallès occidental en los siglos XVIII y XIX: Rubí y Castellbisbal. In Old and New Worlds:The Global Challenges of Rural History. International Conference, Lisbon 27-30 January. https://isbon2016rh.files.wordpress.com/2015/12/ 0181-onw.pdf

Marfany, J. (2012). Land, Proto-Industry and Population in Catalonia, c. 1680-1829: An Alternative Transition to Capitalism? London: Ashgate.

Marull, J., Pino, J., Tello, E. \& Cordobilla, M. J. (2010). Social Metabolism, Landscape Change and Land-Use Planning in the Barcelona Metropolitan Region. Land Use Policy, 27 (2), 497-510.

Milanovic, B. (2010). Level of Income and Income Distribution in mid-18th Century France, according to Francois Quesnay. World Bank Policy Research Working Paper, (10545). http://ssrn.com/abstract $=1731370$

Milanovic, B. (2011). A Short History of Global Inequality:The Past two Centuries. Explorations in Economic History, 48 (4), 494-506.

Milanovic, B., Lindert, P. H. \& Williamson, J. G. (2011). Pre-Industrial Inequality. The Economic fournal, 121 (551), 255-72.

Moreno Luzón, J. (2007). Political Clientelism, Elites, and Caciquismo in Restoration Spain (1875-1923). European History Quarterly, 37 (3), 417-41.

Moreno Ramírez, P. (2011[1858]). Estadística territorial de la provincia de Barcelona. [Facsimile edition and introductory study by J. I. Muro, F. Nadal \& L. Urteaga]. Barcelona: Societat Catalana de Geografia.

Morner, M. (1970). A Comparative Study of Tenant Labor in Parts of Europe, Africa and Latin America 1700-1900: A Preliminary Report of a Research Project in Social History. Latin American Research Review, 5 (2), 3-15.

Muro, J. I., NAdAL, F. \& URTEAGA, L. (1996). Geografía, estadística y catastro en España: 1856-1870. Barcelona: Ediciones del Serbal. 
NADAl, J. \& Giralt, E. (1960). La population catalane de 1553 à 1717: L'immigration française et les autres facteurs de son développement. Paris: SEVPEN.

Olarieta, J. R., Rodríguez Valle, F. L. \& Tello, E. (2008). Preserving and Destroying Soils, Transforming Landscapes: Soils and Land-Use Changes in the Vallès County (Catalunya, Spain) 1853-2004. Land Use Policy, 25 (4), 474-84.

O’Rourke, K. H. \& Williamson, J. G. (1999). Globalization and History: The Evolution of a Nineteenth-Century Atlantic Economy. Cambridge: MIT Press.PeÑa, C. DE LA (1852). Tratado de estadística territorial y pecuaria, acompañado de un reglamento general para su establecimiento y conservación. Pontevedra: Imprenta de N. Pazos y José Antunez.

PIKeTty, T. (2014). Capital in the Twenty-First Century. Cambridge: Harvard University Press.

Piketty, T., Postel-Vinay, G. \& Rosenthal, J. L. (2006). Wealth Concentration in a Developing Economy: Paris and France, 1807-1994. American Economic Review, 96 (1), 236-56.

Prados de LA Escosura, L. (2008). Inequality, Poverty and the Kuznets Curve in Spain, 1850-2000. European Review of Economic History, 12 (3), 287-324.

Roine, J. \& WALDENSTRÖM, D. (2009). Wealth Concentration over the Path of Development: Sweden, 1873-2006. The Scandinavian fournal of Economics, 111 (1), 151-87.

SAn Julián, F. J. (2011). Political Economy and Tax Reform in Parliament: Spain's Attempt to implement Income Tax in 1868-1869. Revista de Historia Económica-fournal of Iberian and Latin American Economic History, 29 (2), 245-68.

SANTIAGO-CABALLERO, C. (2011). Income Inequality in Central Spain, 1690-1800. Explorations in Economic History, 48 (1), 83-96.

Schlumbohm, J. (1996). Micro-History and the Macro-Model of the European Demographic System in Pre-Industrial Times: Life Course Patterns in the Parish of Belm (Nortwest Germany), Seventeenth to the Nineteenth Centuries. The History of the Family, (1), 81-95.

SEgurA, A. (1993). Burgesia $i$ propietat de la terra a Catalunya en el segle XIX: Les comarques barcelonines. Barcelona: Curial.

SEN, A. K. (1959). The Choice of Agricultural Techniques in Underdeveloped Countries. Economic Development and Cultural Change, 7 (3), 279-85.

Shenk, M. K., Borgerhoff Mulder, M., Beise, J., Clark, G., Irons, W., Leonetti, D., Low, B. S., Bowles, S., Hertz, T., Bell, A. \& Piraino, P. (2010). Intergenerational Wealth Transmission among Agriculturalists. Current Anthropology, 51 (1), 6583.

Simpson, J. (2011). Creating Wine: The Emergence of a World Industry, 1840-1914. Princeton: Princeton University Press.

Stiglitz, J. E. (2012). The Price of Inequality. New York: W.W. Norton \& Co. 
Tello, E. (1997). La conflictividad social en el mundo rural catalán, del Antiguo Régimen a la Revolución liberal, 1720-1833. Noticiario de historia agraria, 7 (13), 89-104.

Tello, E. \& BADiA-Miró, M. (2015). L'expansió de la frontera interior: Un model per explicar l'especialització vitícola catalana (1720-1939). In J. Colomé, J. Planas \& F. VALLs-JUNYENT (Eds.), Vinyes, vins i cooperativisme vitivinicola a Catalunya (pp. 5181). Barcelona: Publicacions de l'Abadia de Montserrat.

Tello, E., Garrabou, R. \& Cussó, X. (2006). Energy Balance and Land Use:The Making of an Agrarian Landscape from the Vantage Point of Social Metabolism. In M. AGNOLETTI (Ed.), The Conservation of Cultural Landscapes (pp. 42-56). Wallingford: CABI.

VALls-JuNYENT, F. (1997). Contractació a rabassa morta i conjuntura vitícola a Catalunya, 1720-1850. Estudis històrics $i$ documents dels arxius de protocols, (XV), 229-34.

VALls-JunYent, F. (2004). Viticulture et industrialisation en Europe du Sud: Les cas du Languedoc, du Portugal et de la Catalogne. Domitia, (5), 41-51.

VILAR, P. (1962). La Catalogne dans l'Espagne moderne: Recherches sur les fondements économiques des structures nationales. Paris: SEVPEN.

VRIES, J. DE (2010). The Limits of Globalization in the Early Modern World. The Economic History Review, 63 (3), 710-33.

Williamson, J. G. (1991). Inequality, Poverty, and History: The Kuznets Memorial Lectures of the Economic Growth Center,Yale University. Cambridge: Basil Blackwell.

Williamson, J. G. (1999). Real Wages, Inequality and Globalization in Latin America before 1940. Revista de Historia Económica-fournal of Iberian and Latin American Economic History, 17 (1), 101-42.

Williamson, J. G. (2009). Globalization and the Poor Periphery before 1950. Cambridge: MIT Press.

ZANDEN, J. L. van (1995). Tracing the Beginning of the Kuznets Curve: Western Europe during the Early Modern Period. The Economic History Review, 48 (4), 643-64. 


\section{ANNEX}

TABLE A1

Number of taxpayers in the Distribution of Personal Wealth in Real Estate Ownership of 1852 in the province of Barcelona

\begin{tabular}{lccccr}
\hline $\begin{array}{l}\text { Districts of the province } \\
\text { of Barcelona }\end{array}$ & All & With less than 2,000 reales & $\%$ & With less than 1,500 reales & \% \\
\hline Barcelona & 11,940 & 7,642 & 64.0 & 7,004 & 58.7 \\
Arenys & 6,774 & 6,161 & 91.0 & 5,980 & 88.3 \\
Berga & 3,657 & 2,970 & 81.2 & 2,820 & 77.1 \\
Granollers & 8,384 & 7,608 & 90.7 & 7,447 & 88.8 \\
Igualada & 9,852 & 9,055 & 91.9 & 8,785 & 89.2 \\
Manresa & 9,561 & 8,796 & 92.0 & 8,601 & 90.0 \\
Mataró & 5,326 & 4,748 & 89.1 & 4,576 & 85.9 \\
Sant Feliu de Llobregat & 8,673 & 8,021 & 92.5 & 7,834 & 90.3 \\
Terrassa & 8,276 & 7,659 & 92.5 & 7,491 & 90.5 \\
Vic & 7,356 & 6,430 & 87.4 & 6,242 & 84.9 \\
Vilafranca del Penedès & 6,500 & 5,676 & 87.3 & 5473 & 84.2 \\
Province of Barcelona & 86,299 & 74,766 & 86.6 & 72,253 & 83.7 \\
\hline
\end{tabular}

Source: our own, from the Distribution of Personal Wealth in Real Estate Ownership of 1852 in the province of Barcelona (Library of the Universitat de Barcelona, reference 146-1-II/13). 
TABLE A2

Taxes paid and tax burden of taxpayers above and below an attributed cadastral income of 2,000 reales a year in the province of Barcelona, according to the Distribution of Personal Wealth in Real Estate Ownership of 1852 (in reales a year or percentaje)

\begin{tabular}{lcrrrrr}
\hline Districts of the province & Estimated cadastral & \multicolumn{5}{c}{ Taxpayers with more than 2,000 reales } \\
\hline of Barcelona & income of all taxpayers & $\begin{array}{c}\text { Estimated cadastral \% of all income } \\
\text { income }\end{array}$ & $\begin{array}{r}\text { Taxes } \\
\text { attributed }\end{array}$ & $\begin{array}{r}\text { \% of all } \\
\text { paid }\end{array}$ & $\begin{array}{c}\text { \% of tax } \\
\text { taxes paid }\end{array}$ & burden \\
\hline Barcelona & $40,745,709$ & $36,242,839$ & 88.9 & $4,447,032$ & 87.4 & 12.3 \\
Arenys & $5,918,547$ & $3,362,731$ & 56.8 & 513,458 & 55.6 & 15.3 \\
Berga & $5,061,354$ & $3,708,250$ & 73.3 & 541,062 & 68.5 & 14.6 \\
Granollers & $7,774,228$ & $5,178,452$ & 66.6 & 812,785 & 66.3 & 15.7 \\
Igualada & $6,778,104$ & $3,579,993$ & 52.8 & 629,203 & 50.2 & 17.6 \\
Manresa & $6,933,038$ & $4,343,674$ & 62.7 & 755,428 & 60.5 & 17.4 \\
Mataró & $5,076,673$ & $2,980,214$ & 58.7 & 472,361 & 57.0 & 15.8 \\
Sant Feliu de Llobregat & $6,555,209$ & $3,710,259$ & 56.6 & 606,685 & 55.1 & 16.4 \\
Terrassa & $6,571,379$ & $3,781,913$ & 57.6 & 580,909 & 57.3 & 15.4 \\
Vic & $6,994,514$ & $5,110,590$ & 73.1 & $1,039,174$ & 72.2 & 20.3 \\
Vilafranca del Penedès & $7,038,780$ & $4,895,405$ & 69.5 & 890,345 & 68.2 & 18.2 \\
\hline Province of Barcelona & $105,447,534$ & $76,894,320$ & 72.9 & $11,288,442$ & 69.6 & 14.7 \\
\hline
\end{tabular}

\begin{tabular}{lcccccc}
\hline Districts of the province & Estimated cadastral & \multicolumn{5}{c}{ Taxpayers with less than 2,000 reales } \\
\hline of Barcelona & income of all taxpayers & $\begin{array}{c}\text { Estimated cadastral \% of all income } \\
\text { income }\end{array}$ & $\begin{array}{c}\text { Taxes } \\
\text { attributed }\end{array}$ & $\begin{array}{c}\text { \% of all } \\
\text { paid }\end{array}$ & $\begin{array}{c}\text { \% of tax } \\
\text { taxes paid }\end{array}$ & burden \\
\hline Barcelona & $5,087,106$ & $4,502,870$ & 11.1 & 640,074 & 12.6 & 14.2 \\
Arenys & 923,500 & $2,555,816$ & 43.2 & 410,042 & 44.4 & 16.0 \\
Berga & 790,410 & $1,353,104$ & 26.7 & 249,348 & 31.5 & 18.4 \\
Granollers & $1,225,356$ & $2,595,776$ & 33.4 & 412,571 & 33.7 & 15.9 \\
Igualada & $1,252,699$ & $3,198,111$ & 47.2 & 623,496 & 49.8 & 19.5 \\
Manresa & $1,249,441$ & $2,589,364$ & 37.3 & 494,013 & 39.5 & 19.1 \\
Mataró & 829,013 & $2,096,459$ & 41.3 & 356,653 & 43.0 & 17.0 \\
Sant Feliu de Llobregat & $1,100,946$ & $2,844,950$ & 43.4 & 494,261 & 44.9 & 17.4 \\
Terrassa & $1,013,776$ & $2,789,466$ & 42.4 & 432,866 & 42.7 & 15.5 \\
Vic & $1,439,601$ & $1,883,924$ & 26.9 & 400,427 & 27.8 & 21.3 \\
Vilafranca del Penedès & $1,304,541$ & $2,143,375$ & 30.5 & 414,196 & 31.8 & 19.3 \\
\hline Province of Barcelona & $16,216,389$ & $28,553,214$ & 27.1 & $4,927,947$ & 30.4 & 17.3 \\
\hline
\end{tabular}

Source: our own, from the Distribution of Personal Wealth in Real Estate Ownership of 1852 in the province of Barcelona (Library of the Universitat de Barcelona, reference 146-1-II/13). 